\title{
UPAYA PENINGKATAN PRODUKSI KOPI DENGAN PANEN PETIK MERAH DI KABUPATEN REJANG LEBONG
}

\section{EFFORTS TO INCREASE COFFEE PRODUCTION WITH RED POWDER HARVEST IN REJANG LEBONG DISTRICT}

\author{
Afrizon, Andi Ishak dan Darkam Mussaddad \\ Balai Pengkajian Teknologi Pertanian Bengkulu \\ e-mail: afrizon41@yahoo.co.id
}

\begin{abstract}
ABSTRAK
Produksi kopi yang dihasilkan masih rendah karena petani tidak menerapkan teknologi budidaya kopi sesuai dengan rekomendasi. Teknologi tersebut mulai dari teknologi pembibitan, budidaya, sampai dengan panen dan pascapanen. Penelitian ini bertujuan untuk membandingkan produksi kopi dengan penerapan panen petik merah dan petik pelangi. Penelitian dilakukan di Desa Tanjung Beringin, Kecamatan Curup Utara, Kabupaten Rejagn Lebong dari bulan April sampai bulan September 2019. Variabel yang diamati adalah biaya panen, pascapanen, dan pemasaran kopi petik merah dan petik pelangi. Pengamatan juga dilakukan terhadap berat sampel panen kopi petik merah dan petik pelangi. Analisis data secara deskriptif menggunakan MBCR. Hasil kajian menunjukkan bahwa dengan penerapan panen kopi petik merah dapat meningkatkan produksi kopi sebanyak 30\% dan meningkatkan pendapatan petani sebanyak Rp 2.295 .000 (51,4 \%) dibandingkan dengan penerapan panen petik pelangi.
\end{abstract}

Kata Kunci : Kopi; Panen petik merah; Produksi

\begin{abstract}
The resulting coffee production is still low because farmers do not implement coffee cultivation technology in accordance with the recommendations. The technology starts from nursery, cultivation, until harvest and post-harvest technology. This study aims to compare the production of coffee with the application of harvesting red picks and rainbow picking. The study was conducted in Tanjung Beringin Village, Curup Utara District, Rejagn Lebong Regency from April to September 2019. The variables observed were harvesting costs, postharvesting, and marketing of red picking coffee and picking rainbows. Observations were also made on the weight of the harvest samples of red picking and rainbow picking. Descriptive data analysis using MBCR. The results of the study show that by applying red picking coffee harvests can increase coffee production by 30\% and increasing farmers' income by Rp 2,295,000 (51.4\%) compared to the application of the harvest of picking rainbows.
\end{abstract}

Keywords: Coffee; Red Harvest; Production 


\section{PENDAHULUAN}

Tanaman kopi merupakan salah satu sumber pendapatan bagi petani di Kabupaten Rejang Lebong. Namun kesejahteraan petani kopi masih rendah karena pendapatan dari usahatani komoditas ini juga masih rendah. Produktivitas kopi rata-rata di Kabupaten Rejang Lebong sekitar $700 \mathrm{~kg} / \mathrm{ha} /$ tahun (BPS, 2016) dan masih tergolong rendah. Salah satu penyebabnya adalah petani belum umum melakukan penyambungan kopi menggunakan klon unggul Beragam permasalahan yang dapat dijadikan alasan rendahnya produktivitas kopi di Kabupaten Rejang Lebong. Alasan harga kopi yang rendah disertai dengan produktivitasnya yang juga rendah membuat petani tidak dapat mengandalkan usahatani kopi sebagai sumber pendapatan utama. Kondisi ini menyebabkan petani kurang memprioritaskan pemeliharaan kopi untuk sumber pendapatan utama.

Petani hanya mengurus kebun kopi pada saat panen selama kurun waktu sekitar 3 bulan yaitu sejak bulan April sampai dengan Juni setiap tahunnya karena pendapatan dari kopi yang belum dapat dijadikan sebagai sumber pendapatan utama. Selama setahun rata-rata petani hanya mendapatkan penerimaan sekitar 12 juta rupiah dari satu hektar kebun kopi. Apabila dikurangi dengan biaya-biaya usaha tani yang dikeluarkan, tentu jumlah yang diterima petani juga semakin kecil. Rendahnya penerimaan tersebut karena harga beras kopi (green bean) di tingkat petani rendah yaitu sekitar Rp.17.000/kg. Rendahnya harga kopi ini menyebabkan petani kurang bersemangat mengurus tanaman kopinya.

Apabila diasumsikan dalam 1 musim kopi, petani mengeluarkan biaya sebesar 2 juta rupiah, maka pendapatan bersih dari usahatani kopi tinggal 10 juta rupiah per bulan. Jumlah ini apabila dirataratakan hanya tinggal sekitar 800-an ribu per bulan, suatu jumlah yang tidak dapat mencukupi seluruh kebutuhan keluarga petani. Hal inilah yang menyebabkan usahatani kopi merupakan usahatani sampingan bagi kebanyakan petani di Rejang Lebong.

Curahan waktu tenaga kerja pada usahatani sampingan hanya dilakukan pada saat panen di musim kopi (April s/d Juni). Tentu saja curahan waktu tersebut menyebabkan petani tidak memelihara tanamannya dengan baik. Dari generasi ke generasi budidaya kopi masih dilakukan petani secara tradisional.

Meskipun pendapatan dari 
usahatani kopi relatif rendah, namun tanaman ini seringkali dijadikan agunan petani kepada para pedagang pengumpul kopi (tengkulak kopi). Lebih dari 50\% petani kopi di Kelompok Tani Paksi Jaya berhutang kepada tengkulak. Hutang petani kepada tengkulak menyebabkan daya tawar petani terhadap harga kopi rendah. Tengkulaklah yang menentukan harga sesuai dengan kondisi pasar menurut para tengkulak dan yang tidak dipahami petani. Kondisi seperti ini sudah berlangsung cukup lama. Untuk meningkatkan produksi dan harga jual kopi ditingkat petani telah dilakukan kajian. Tujuan kajian adalah untuk membandingkan produksi kopi dengan penerapan panen petik merah dan petik pelangi.

\section{METODE PENELITIAN}

Kajian ini dilakukan di Desa Tanjung Beringin Kecamatan Curup Utara Kabupaten Rejang Lebong dari bulan April sampai bulan September 2019. Pelaksanaan kajian menggunakan metode Deskriptif dan pengamatan langsung di lapangan. Melibatkan kelompok tani Paksi Jaya yang tergabung dalam Kelembagaan BUMP Bukit Kaba Mandiri. Untuk pengambilan sampel dilakukan panen petik merah sebanyak 2 kaleng $(32 \mathrm{~kg})$ dan langsung diolah secara basah selanjutnya dilakukan pengeringan serta penimbangan 100 biji sebanyak 5 sampel, kemudian dirata ratakan. Hasil penimbangan berat 100 biji ini kemudian dibandingkan beratnya dengan biji kopi yang dipanen pelangi. Selanjutnya data diolah secara deskriptif dengan menggunakan metode Marginal Benefit Cost Ratio (MBCR) untuk melihat besarnya produksi dan perbandingan tingkat harga serta pendapatan dengan penerapan panen petik merah.

\section{HASIL DAN PEMBAHASAN}

\section{Kondisi Existing Usahatani Kopi}

Sebagian besar petani tidak menerapkan teknologi budidaya kopi sesuai dengan rekomendasi. Teknologi tersebut mulai dari teknologi pembibitan, budidaya, sampai dengan panen dan pascapanen. Petani masih belum menggunakan klon unggul. Klon kopi yang digunakan adalah klon lokal yang diperbanyak secara tradisional dengan sistem generatif (perbanyakan dengan biji). Petani juga belum menggunakan pupuk spesifik lokasi sesuai dengan kebutuhan tanaman. Panen masih dengan cara "petik pelangi" yang menyebabkan kualitasnya rendah. 
Berdasarkan penelusuran di lapangan, terdapat hanya $50 \%$ petani yang pernah melakukan penyambungan kopi dengan klon unggul lokal. Klon unggul lokal ini dipilih berdasarkan criteria berbuah banyak namun belum pemperhatikan ketahanan terhadap hama dan penyakit tanaman kopi. Pemupukan anorganik (pupuk kimia) merupakan teknologi yang relatif sulit diterapkan petani di desa ini. Hal ini karena dibutuhkan biaya yang cukup besar yang relatif tidak mudah dipenuhi oleh petani. Oleh karena itu, tim Bioindustri BPTP Bengkulu menganjurkan agar petani mengintensifkan penggunaan kompos terutama yang berasal dari limbah kulit kopi yang masih belum banyak dimanfaatkan oleh petani kopi setempat. Potensi limbah kopi untuk bahan kompos cukup banyak tersedia. Hasil penelitian yang pernah dilakukan sebelumnya menyatakan bahwa potensi limbah kulit kopi yang ada di Kabupaten Rejang Lebong sebanyak dan tersebar di setiap kecamatan di Kabupaten Rejang Lebong dan belum banyak dimanfaatkan. .

\section{Introduksi Inovasi Budidaya Anjuran}

Sebagai salah satu titik unggkit peningkatan produksi kopi maka BPTP
Bengkulu telah melakukan introduksi panen petik merah dan pelatihan penyambungan kopi menggunakan klon unggul Nasional yang berasal dari daerah Kabupaten Rejang Lebong. Hasil penerapan inovasi penyambungan kopi yang dilakukan BPTP Bengkulu untuk meningkatkan produksi baru mencapai $30 \%$, yang menandakan bahwa petani belum terampil melakukan penyambungan kopi. Permasalahan lainnya adalah petani merasa kesulitan mendapatkan entres klon unggul dan harganya mahal. Permasalahan mendapatkan klon unggul dan rendahnya keterampilan petani dalam penyambungan kopi telah difasilitasi penyelesaiannya oleh tim Bioindustri BPTP Bengkulu pada saat pelatihan penyambungan tanaman kopi menggunakan klon unggul. Pada saat itu, telah dipertemukan petani Kelompok Tani Paksi Jaya dengan penangkar kopi dari Kecamatan Sindang Dataran. Petani diperkenalkan dengan 4 klon unggul kopi yaitu Sintaro 1, Sintaro 2, Sintaro 3, dan Sehasence yang entresnya telah tersedia di kebun penangkar. Pada saat dilakukan pelatihan dilakukan juga penyambungan 600 entres di kebun petani, masing-masing 150 entres setiap klon. Hasilnya tingkat keberhasilan penyambungan kopi menggunakan klon unggul mencapai $75 \%$. 
Dari inisiasi inovasi panen petik merah dan pelatihan pengolahan kopi secara basah,

Saat ini petani telah mampu menghasilkan biji kopi petik merah secara kontinyu dan hasilnya mulai dijual kepada pedagang di Bengkulu maupun di luar provinsi. Inovasi teknologi yang diuraikan di atas diharapkan dapat meningkatkan produktivitas kopi dan pendapatan petani secara berkelanjutan. Disamping dapat meningkatkan produksi juga meningkatkan mutu kopi yang dihasilkan. Menurut Tarigan, et al (2017), mutu kimia kopi bubuk berupa kadar lemak dan kadar kafein dipengaruhi oleh interaksi antara tingkat kematangan buah, lama fermentasi, dan penyangraian. Kadar air dan protein dipengaruhioleh interaksi antara tingkat kematangan buah dengan lama fermentasi, dan interaksi antara tingkat kematangan buah dan lama penyangraian. Kadar abu dipengaruhi oleh lama penyangraian, dan $\mathrm{pH}$ dipengaruhi oleh lama fermentasi dan penyangraian.

Harga kopi petik merah yang diterima petani lebih tinggi dibandingkan dengan petik pelangi. Harga beras kopi petik pelangi pada saat ini adalah $\mathrm{Rp}$. 17.000/kg, sedangkan harga beras kopi petik merah Rp. 35.000/kg atau sekitar dua kali lipat dari beras kopi panen pelangi.
Dengan peningkatan harga kopi melalui inovasi panen petik merah yang dinikmati petani, maka petani akan berupaya untuk meningkatkan produksi. Teknologi kompos dan penggunaan klon unggul mampu meningkatkan produksi kopi, namun perlu adanya penambahan tenaga kerja dan biaya yang relatif lebih besar. Artinya bahwa meskipun penggunaan klon dan kompos mampu meningkatkan dua kali lipat produksi, masih sama dengan panen kopi petik merah tanpa mengeluarkan biaya.

Ditinjau dari aspek sosial budaya, petani lebih mudah mengadopsi teknologi panen petik merah dibandingkan dengan pertimbangan aspek teknis dan lingkungan. Hal ini karena tidak dibutuhkan tenaga kerja yang relatif lebih banyak dibandingkan dengan teknologi panen petik pelangi yang telah biasa diterapkan petani. Hanya dengan merubah cara panen petani mampu meningkatkan produksi.

Sisi teknis dan lingkungan merupakan hal yang kurang berpengaruh dalam pemilihan teknologi. Aspek teknik terkait dengan keterampilan petani, sedangkan aspek lingkungan terkait dengan kondisi agroekosistem. Petani dapat mengupah tenaga kerja apabila 
memiliki keuntungan yang lebih dari panen petik merah untuk melakukan perbaikan klon tanaman kopi. Kompos juga dapat disiapkan dengan modal yang tersedia dari hasil penjualan kopi. Artinya bahwa, apabila panen kopi petik merah dapat dilakukan dan bermanfaat bagi petani, maka penggunaan klon unggul dan kompos dapat mengikuti untuk meningkatkan produksi kopi. Hal ini berarti pilihan BPTP Bengkulu untuk lebih memprioritaskan panen kopi petik merah memiliki pijakan yang kuat dalam peningkatan produksi dan pendapatan petani kopi di lokasi percontohan Kabupaten Rejang Lebong.

Keuntungan yang diperoleh dari pengolahan kopi petik merah menjadi beras kopi sebesar Rp.16.214/kg lebih tinggi 2,5 kali lipat dibandingkan dengan petik pelangi yang keuntungannya sebesar Rp. 6.478/kg. Pengolahan kopi panen petik merah meningkatkan biaya produksi sebesar Rp. 7.264/kg dibandingkan dengan petik pelangi. Namun keuntungan yang diperoleh juga lebih tinggi yaitu sebesar Rp. 9.736/kg.

Tabel 1. Perbandingan analisa usahatani panen dan pasca panen kopi petik merah dan petik pelangi.

\begin{tabular}{|c|c|c|c|c|c|c|}
\hline \multirow[b]{2}{*}{ No. } & \multirow[b]{2}{*}{ Uraian } & \multirow[b]{2}{*}{ Volume } & \multicolumn{2}{|c|}{ Petik merah (Rp) } & \multicolumn{2}{|c|}{ Petik pelangi (Rp) } \\
\hline & & & $\begin{array}{l}\text { Harga } \\
\text { satuan }\end{array}$ & Jumlah harga & $\begin{array}{l}\text { Harga } \\
\text { satuan }\end{array}$ & Jumlah harga \\
\hline A. & Biaya panen dan pasca panen & & & & & \\
\hline 1. & Biaya panen buah kopi & 45 kaleng* & 25.000 & 1.125 .000 & 12.500 & 562.500 \\
\hline 2. & $\begin{array}{l}\text { Upah sortasi dan } \\
\text { memisahkan biji dengan } \\
\text { kulit buah menggunakan } \\
\text { pulper }\end{array}$ & $720 \mathrm{~kg}$ & 199 & 143.280 & - & - \\
\hline 3. & $\begin{array}{l}\text { Biaya pemeraman dan } \\
\text { pencucian }\end{array}$ & $495 \mathrm{~kg}$ & 109 & 53.955 & - & - \\
\hline \multirow[t]{2}{*}{4.} & Biaya penjemuran & $495 \mathrm{~kg}$ & 500 & 247.500 & - & - \\
\hline & & $720 \mathrm{~kg}$ & - & & 500 & 360.000 \\
\hline \multirow[t]{3}{*}{5.} & Biaya penggilingan & $135 \mathrm{~kg}$ & 500 & 67.500 & 500 & 67.500 \\
\hline & $\begin{array}{l}\text { Total biaya panen dan pasca } \\
\text { panen }\end{array}$ & - & - & 1.637 .235 & - & 990.000 \\
\hline & $\begin{array}{l}\text { Total biaya panen dan pasca } \\
\text { panen per kg }\end{array}$ & - & - & 12.128 & - & 7.333 \\
\hline B. & Penjualan beras kopi & $135 \mathrm{~kg}$ & 35.000 & 4.725 .000 & 18.000 & 2.430 .000 \\
\hline C. & Keuntungan & $135 \mathrm{~kg}$ & - & 3.087 .765 & - & 1.440 .000 \\
\hline D. & Nilai MBCR & & & 2,55 & & \\
\hline
\end{tabular}

Keterangan: 45 kaleng kopi $=720$ kg kopi. 
Dengan demikian, nilai MBCR panen kopi petik merah sebesar 1,34. Hal ini berarti bahwa setiap penambahan 100 Rupiah pada inovasi kopi panen petik merah, petani mendapatkan keuntungan 1,34 Rupiah. Oleh karena itu, inovasi teknologi panen petik merah secara finansial layak direkomendasikan.

Pengolahan hasil biji kopi panen petik merah lebih kompleks daripada panen pelangi. Tenaga kerja yang dibutuhkan juga meningkat dua kali lipat pada panen petik merah karena pemanenan dilakukan tidak sekaligus disesuaikan dengan kondisi kematangan buah. Setelah panen petik merah, dilakukan sortasi dan pengelupasan kulit buah. Biji kopi dicuci untuk memisahkan kulit buah dari biji, sebelum dimasukkan ke dalam karung dan diperam selama 12-48 jam. Biji kopi kemudian dijemur selama 7 hari sebelum di giling untuk melepaskan kulit tanduk. Berdasarkan uraian di atas, tentu saja dibutuhkan tenaga kerja yang lebih banyak pada saat panen dan pasca panen kopi petik merah dibandingkan petik pelangi, karena petani langsung menjemur kopi hasil panen petik pelangi. Biaya yang dikeluarkan petani dalam proses panen dan pasca panen kopi petik merah lebih tinggi dibandingkan dengan petik pelangi yaitu berturut-turut Rp. $12.128 / \mathrm{kg}$ dan Rp. $7.333 / \mathrm{kg}$. Tahapan proses pengolahan biji kopi petik merah dan petik pelangi di Poktan Paksi Jaya ditampilkan pada Gambar 1.

Gambar 1 memperlihatkan bahwa tahapan proses pengolahan panen petik merah lebih panjang daripada petik pelangi. Petani memerlukan waktu dua kali lebih lama untuk memanen kopi dengan cara petik merah dibandingkan dengan petik pelangi. Selanjutnya kopi petik merah diolah melalui beberapa tahap sebelum dijemur. Sementara itu, kopi yang dihasilkan dengan cara panen petik pelangi langsung dijemur sekitar 7-10 hari sebelum digiling. Pengolahan biji kopi petik merah setelah dipanen adalah disortir, dikupas kulit dagingnya dengan mesin pulper, difermentasi, dicuci, dan selanjutnya baru dijemur. Proses pengolahan sampai tahap sebelum penjemuran membutuhkan waktu 2-3 hari. Masa penjemuran kopi panen petik merah berlangsung lebih cepat dibandingkan dengan petik yaitu antara 4-6 hari sebelum digiling untuk membuang kulit tanduknya. 

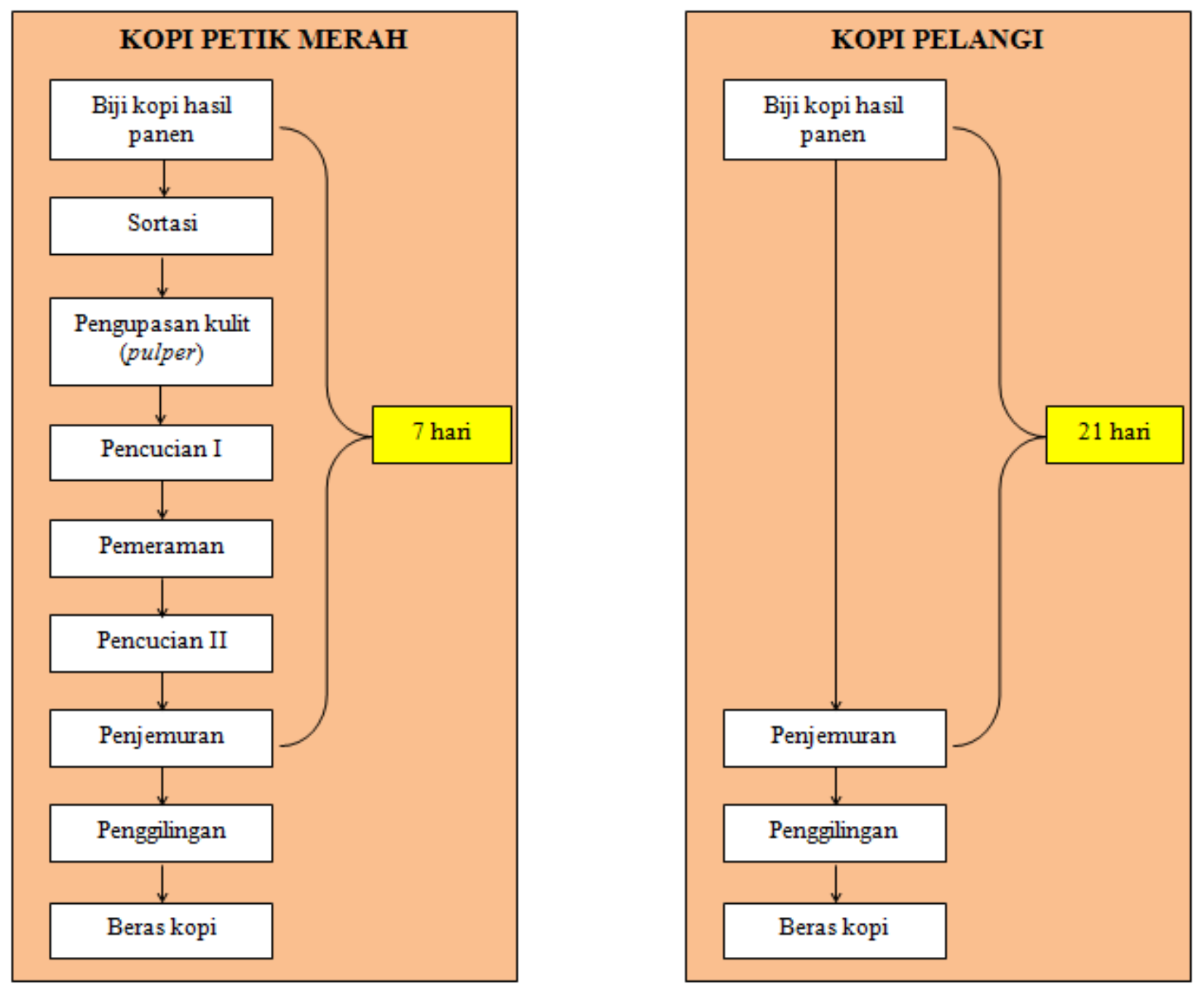

Gambar 1. Tahapan Proses Panen dan Pasca Panen Kopi Petik Merah dan Petik Pelangi.

Meskipun petani mengeluarkan biaya yang lebih tinggi, namun panen petik merah memiliki tiga keunggulang dibandingkan dengan petik pelangi. Pertama, proses pasca panen dari biji kopi sampai dengan beras kopi lebih cepat yaitu hanya membutuhkan waktu sekitar 7 hari dari waktu petik sampai selesai penjemuran.
Sementara itu, kopi petik pelangi memerlukan waktu 21 hari. Ada penghematan waktu 2 minggu dari proses ini. Kedua, panen petik merah lebih menguntungkan. Nilai MBCR panen kopi petik merah sebesar 2,55 dibandingkan dengan petik pelangi. Hal ini berarti bahwa setiap penambahan 1 rupiah biaya panen 
dan pasca panen, petani mendapatkan keuntungan 2,55 rupiah. Ketiga, panen petik merah memiliki produktivitas hasil lebih tinggi dibandingkan dengan petik pelangi. Berdasarkan hasil penimbangan rata rata, berat 100 biji kopi petik merah adalah 167,06 gr, sedangkan petik pelangi 137,43 gr. Oleh karena itu, rata-rata biji kopi panen petik merah lebih berat 0,3 gr dibandingkan dengan petik pelangi. Menurut Yusianto (2016) buah kopi yang dipanen matang sempurnya secara fisiologis akan memiliki kepadatan buah dan mutu yang baik yang ditandai buah berwarna merah yaitu buah yang sudah berumur $10-11$ bulan.

Berdasarkan uraian keunggulan inovasi panen kopi petik merah dari sisi teknis (lebih tinggi produktivitasnya), ekonomis (lebih efisien), dan sosial (petani mulai mencoba menerapkan inovasi), maka diperkirakan inovasi ini dapat diadopsi petani dalam secara luas. Permasalahannya adalah pada kepastian pasar. Sampai saat ini, BUMP baru menjajaki pemasaran kopi petik merah dengan pengolah kopi di BUMP Kecamatan Sindang Dataran. Oleh karena itu, BPTP perlu memfasilitasi petani untuk memastikan pasar tersebut ke depan.

\section{KESIMPULAN}

Penerapan panen petik merah tanaman kopi dapat meningkatkan produksi sebanyak $30 \%$ dibandingkan panen pelangi dan meningkatkan pendapatan petani sebanyak Rp 2.295.000 $(51,4 \%) / 720 \mathrm{~kg}$ buah dibandingkan penerapan panen pelangi.

\section{DAFTAR R PUSTAKA}

BPS Provinsi Bengkulu. 2017. Provinsi Bengkulu dalam Angka. Bengkulu.

Bedy Sudjarmoko. 2013. Prospek Pengembangan Industrialisasi Kopi Indonesia. SIRINOV, Vol 1, No 3, Desember 2013 ( Hal : 99 - 110)

Direktorat jendral Bina Produksi Perkebunan. 2016. Statistik Perkebunan Kopi Indonesia 2016 2017. Direktorat Jendral Bina Produksi Perkebunan. Departemen Pertanian. Jakarta.

Disbun. 2016. Statistik Perkebunan Propinsi Bengkulu. Pemerintah Propinsi Bengkulu.

Karmawati, Rubiyo, Siswanto, Indrawanto, C dan J Munarso. 2010. Budidaya dan Pasca Panen Kopi. . Pusat Penelitian dan Pengembangan Perkebunan. Bogor Prastowo

Saefudin dan Edi Wardiana. 2013. Pengaruh Varietas dan Tingkat Kematangan Buah Terhadap Perkecambahan dan Fisik Benih Kopi Arabika Buletin RISTRI 4 (3): 245-256 November, 2013

Tarigan. E dan Juniaty T. 2017. Pengaruh Tingkat Kematangan Buah Serta lama Fermentasi dan Penyangraian Biji Terhadap Karakter Fisikokimia Kopi Ronusta. Jurnal tanaman Industri dan Penyegar.Vol 4 no.3. Balai Penelitian Tanaman Industri dan Penyegar(Balittri) 
Lafran Habibi, 2009. Pembuatan Pupuk Kompos Dari Limbah Rumah Tangga. Penerbit Titian Ilmu : Bandung.

Spillane J, J. 1990. Komoditi Kopi, Peranannya dalam Perekonomian Indonesia. Kanisius. Yogyakarta.

Sudarto, Yohaner dan RD Medionovianto. Karakteristik dan Alternatif Teknologi Budidaya Kopi (Studi Kasus di Desa Rempek Kecamatan Rangga Kabupaten Lombok Utara). Prosiding Seminar Nasional Inovasi Teknologi Pertanian Spesifik Lokasi. Kendari 2013. Balai Besar Pengkajian dan Pengembangan Teknologi Pertanian.
Sakiroh, Sobari dan Maman Herman. 2010. Pertumbuhan, Produksi, dan Cita Rasa Kopi pada Berbagai Tanaman Penaung. Prosiding Seminar Nasional Inovasi Teknologi Kopi. Puslit Kopi dan Kakao. Jember

Sobari, Sakiroh dan Eko Purwanto. 2012. Pengaruh jenis tanaman penaung terhadap Pertumbuhan dan persentase tanaman berbuah Pada tanaman Kopi. Bulletin Ristri 3 (3):217-222. Balittri Bogor

Yusianto. (2016). Panen dan pengolahan produk hulu kopi dalam: Kopi "sejarah, botani, proses produksi, pengolahan, produk hilir dan sistem kemitraan. Yogyakarta: UGM Press. 